\title{
Perspectives of using Potassium on Agronomic, Bio Chemical and Yield Parameters of selected Cotton Varieties under Combined Stress of Salinity and Boron
}

\author{
Muhammad Aftab ${ }^{1 *}$, Aneela Riaz ${ }^{2}$, Ghulam Sarwar ${ }^{3}$, Muhammad Arif', Qudsia Nazir', Ifra Saleem ${ }^{1}$, \\ Sarfraz Hussain ${ }^{1}$, Abid Alii ${ }^{4}$ Abid Niaz ${ }^{1}$, Fakhar Mujeeb ${ }^{4}$, Khalid Mahmood ${ }^{5}$ and Sarfraz Nawaz
}

${ }^{1}$ Institute of Soil Chemistry and Environmental Sciences, AARI, Faisalabad, Pakistan; ${ }^{2}$ Soil and Water Testing Lab, Nankana Sabib, Pakistan; ${ }^{3}$ Depatment of Soil and Environmental Sciences, College of Agriculture, University of Sargodha, Sargodha, Pakistan; ${ }^{4}$ Soil Bacteriology Section, Agri. Biotechnology Research Institute, AARI, Faisalabad, Pakistan; ${ }^{5}$ Soil and Water Testing Lab, Toba Tek Singh, Pakistan; ${ }^{6}$ Pesticide Quality Control Laboratory, AARI, Faisalabad, Pakistan.

Abstract | Salt stress interrelates with other stresses as boron toxicity. However, the mechanism involve in salinity-boron interaction is still not well known. This research was carried out to evaluate the plants tolerance under combined stress of B and salt. In combined stresses of (B and Salt) causes oxidative stress in plants due to increase in production of the reactive oxygen species (ROS) including hydroxyl radicals $\left(\mathrm{OH}^{-}\right)$, hydrogen peroxide $\left(\mathrm{H}_{2} \mathrm{O}_{2}\right)$ and superoxide $\left(\mathrm{O}_{2}^{-}\right)$. However, on their side, efficient antioxidant defense system developed in plants, which having lower molecular weight of antioxidants. It also reduces (ROS) enzymatic activities including catalase (CAT), peroxidase (POD) and superoxide dismutase (SOD). Under combined stress conditions agronomic, bio-chemical, quality and over all yield reduces, which is an alarming situation for agriculture sector. To assess the K effect on bio-chemical and agronomic characteristics of selected cotton crop varieties, a lysimeter study was carried out under combined stresses(Salinity and B) conditions. There were two varieties of cotton crop used in this research, such as, 1) FH-114, which was tolerant, and 2) NIAB-846 was sensitive to B-salinity stress. Sodium Chloride $(\mathrm{NaCl})$ and Boric acid $\left(\mathrm{H}_{3} \mathrm{BO}_{3}\right)$ were used to produce salinity and boron toxicity alone or in combined form and potassium $(\mathrm{K})$ was applied as $\left(\mathrm{K}_{2} \mathrm{SO}_{4}\right)$. $\mathrm{K}$ has helpful role under combined stresses (B and salinity) to improve cotton yield. According to the results, the agronomic and growth parameters improved by the application of $\mathrm{K}$. But the toxicity of salinity-boron badly affects the yield and growth parameters in stresses conditions. Received | June 22, 2021; Accepted | October 08, 2021; Published | October 31, 2021

*Correspondence | Muhammad Aftab, Institute of Soil Chemistry and Environmental Sciences, AARI, Faisalabad, Pakistan; Email: m.aftabjee@gmail.com

Citation | Aftab, M., A. Riaz, G. Sarwar, M. Arif, Q. Nazir, I. Saleem, S. Hussain, A. Ali, A. Niaz, F. Mujeeb, K. Mahmood and S. Nawaz. 2021. Perspectives of using potassium on agronomic, bio chemical and yield parameters of selected cotton varieties under combined stress of salinity and boron. Pakistan Journal of Agricultural Research, 34(4): 830-836.

DOI | https://dx.doi.org/10.17582/journal.pjar/2021/34.4.830.836

Keywords | Boron, Potassium, Salinity stress, Chlorophyll content, Cotton

\section{Introduction}

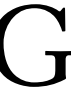
lobally, salinity is a major threat for food security (Syed et al., 2021; Majeed et al., 2010). Toxicity of $\mathrm{B}$ is related to salinity problem described by (Pandey et al., 2019). It has been stated by (Nabal et al., 1997), the B toxicity is a main problem in dry regions of the world, so which can diminish the growth of plants (Camacho et al., 2008). According to literature, $B$ uptake mechanism is still ambiguous in saline conditions. The $\mathrm{B}$ translocation and absorption by passive diffusion may inhibited in salinity conditions and it also reduced transpiration rates. (Kronzucker et al., 2008) has been revealed that, most of the world's soils

December 2021 | Volume 34 | Issue 4 | Page 830 
are salt affected soils (approx. 30\%) that make 1/3 of the world's food. Generally, plants development and growth were gone through in two ways under saline conditions, (Munns and Tester, 2008), i) soil water potential decreases due to osmotic stress, and it also leads to limit the water uptake by plants; ii) excessively in uptake of different ions such as $\left(\mathrm{B}, \mathrm{Cl}^{-}\right.$and $\mathrm{Na}^{+}$) eventually have an effect on the various plants metabolical processes. It has been observed, (Ashraf, 2002), plant reactions to osmotic and ionic mechanisms in saline conditions, are extremely complex for metabolism processes and various gene networks. These forms of reactions primarily depend on different conditions such as, time duration (salts exposure to the roots of plant), severity of salinity and the inherent tolerance of salts in plant. Hasegawa et al., 2000) has been cited that, higher the concentration of $\left(\mathrm{Cl}^{-}, \mathrm{B}\right.$ and $\left.\mathrm{Na}^{+}\right)$nutrients, nutritional imbalance takes place in the plant cells, therefore, decline in assimilation of mineral/nutrients including manganese $(\mathrm{Mn})$, potassium $(\mathrm{K})$ and calcium $(\mathrm{Ca})$ was observed. (Marschner, 1995) has been resulted that in leaf apoplasm, salts toxicity concentrations are increase that it may have adverse effects on leaf cells (dead), dehydration and turgor pressure losses etc. However, if $\mathrm{Na}^{+} /$ $\mathrm{K}^{+}$ratio is higher than dehydration of cells occurred, $\mathrm{Na}$ toxicity concentrations cause hindrance in metabolical processes of plant and the activities of enzymes, (Booth and Beardall, 1991), and hence, these factors contribute towards less growth and low yield of crops. On the other hand, declining in agriculture's production is due to salts accumulation in soils and irrigation water of low quality was used (which is also the major reason in less productivity of agriculture). Literally cited by (Grieve and Poss, 2000), in the arid regions, declining in yield and growth of plant is a rigorous hindering towards agriculture. So, it is not a final solution to get better the plant resistance to salinity conditions, which may decrease the salinization problem through irrigation by reducing inputs and also enhance stability in yield of subsistence agriculture, described by (Flowers and Yeo, 1995).

Potassium $\left(\mathrm{K}^{+}\right)$is a fundamental macronutrient and is a most abundant cation. It also performs vital role in several physiological processes of plant like transport of assimilates, photosynthesis and enzymes activation (Aftab et al., 2016). It influences plant physiological and biochemical activities, (Abbasi et al.,2014), which decrease growth and metabolical process of plant. It has also been found that, it $(K)$ provides survival for plants, when $\mathrm{K}$ exposed to under various biotic and biotic environments. In addition, under certain environmental conditions, $(\mathrm{K})$ is an important nutrient for obtaining high yield of crop, on the other hand, (Liebersbach et al., 2004; Qi and Spalding, 2004), it can be a limiting factor for crops such as water stress and salinity. It has been observed by (Rengel and Damon, 2008) that, illumination of mechanisms responses has main role in plants adaptation to potassium's deficiency.

Cotton (Gossypium birsutum L.) also called as "Queen of fiber", and is the most important crop of Pakistan (Ali et al., 2019). It is mainly grown crop for both oilseed and fiber. Cotton is also grown globally, almost an area of $3106 \mathrm{~kg} \mathrm{ha}^{-1}$ along with average yield of $695 \mathrm{~kg} \mathrm{ha}^{-1}$ and provided productivity of 12968 thousand bales (Rana et al., 2020). Basically, the objective to plan this research was to estimate; i) the yield of two selected cotton varieties under combined stress of boron (B) and salinity, and ii) the role of applied potassium $(\mathrm{K})$ on cotton growth.

\section{Materials and Methods}

\section{Lysimeter experiment}

To assess the influence of potassium (K) on yield, bio-chemical and agronomic parameters of selected cotton varieties (NIAB-846 and FH-114) stress of salinity-boron (in combination) stresses. Therefore, this lysimeter experiment was conducted at the Institute of Soil and Environmental Sciences (ISES), which is located at University of Agriculture (UAF), Faisalabad. Sieving of soil ( $5 \mathrm{~mm}$ mesh size) was done and the Lysimeter were filled with air-dried soil. The samples of soil were collected at normal depth about $(0-15 \mathrm{~cm})$ from soil surface. The texture of soil was sandy clay loam texture $(0.68 \%)$ along with sand (51.5\%), silt (27.75\%) and clay (21.25\%) fractions. Then, other analysis were also assessed as extractable potassium $(\mathrm{K})$, total nitrogen $\left(8.79 \mathrm{mg} \mathrm{N} \mathrm{kg}^{-1}\right)$ and available phosphorous (84 $\mathrm{mg} \mathrm{P} \mathrm{kg}^{-1}$ ), by (Watanabe and Olsen, 1965), and through making standard solutions. After that, the soil physico-chemical properties were calculated as OM $(0.06 \%)$, electrical conductivity $\left(1.41 \mathrm{dS} \mathrm{m}^{-1}\right), \mathrm{pH}(7.9)$, saturated percentage (31.5\%) through following methods of (Moodie et al.,1959; Richards, 1954).

By following all protection measures of plants, tap water of good quality was used for irrigation purpos- 
es. For cotton crop, the nitrogen and phosphorous fertilizers was applied to soil at sowing time with recommended dose of $\mathrm{N}\left(197 \mathrm{~kg} \mathrm{ha}^{-1}\right.$ and $\mathrm{P}\left(94 \mathrm{~kg} \mathrm{ha}^{-1}\right.$. In lysimeter, the soil $\mathrm{K}$ concentration was calculated and added to soils. The remaining levels of $\mathrm{K}^{+}$were applied to soil along with recommended doses and/ or concentrations of $\mathrm{B}$ and salinity were also added to soil artificially as followed by $\left[\mathrm{B}\left(5 \mathrm{mM} \mathrm{H}_{3} \mathrm{BO}_{3}\right)\right.$ + salinity $(140 \mathrm{mM} \mathrm{NaCl})+\left(3\right.$ and $\left.\left.6 \mathrm{mM} \mathrm{K}^{+}\right)\right]$. In treatment $\left(\mathrm{T}_{1}\right)$, the original soil $\left(\mathrm{K}^{+}\right)$was kept as control. Removal of two healthy and uniform seedlings was done after germination for suitable growth of remaining plants.

A set of ten (10) treatments including $\mathrm{T}_{1}=$ Control (original soil $\mathrm{K}^{+}$recommended dose of $\mathrm{N}$ and $\mathrm{P}$ ), $\mathrm{T}_{2}=$ $(140 \mathrm{mM} \mathrm{NaCl}), \mathrm{T}_{3}=(5 \mathrm{mM} \mathrm{B}), \mathrm{T}_{4}=(140 \mathrm{mM} \mathrm{NaCl}$ $+5 \mathrm{mM} \mathrm{B}), \mathrm{T}_{5}=\left(140 \mathrm{mM} \mathrm{NaCl}+3 \mathrm{mM} \mathrm{K}^{+}\right), \mathrm{T}_{6}=$ $\left(140 \mathrm{mM} \mathrm{NaCl}+6 \mathrm{mM} \mathrm{K}^{+}\right), \mathrm{T}_{7}=(5 \mathrm{mM} \mathrm{B}+3 \mathrm{mM}$ $\left.\mathrm{K}^{+}\right), \mathrm{T}_{8}=\left(5 \mathrm{mM} \mathrm{B}+6 \mathrm{mM} \mathrm{K}^{+}\right), \mathrm{T}_{9}=(140 \mathrm{mM} \mathrm{NaCl}+$ $\left.5 \mathrm{mM} \mathrm{B}+3 \mathrm{mM} \mathrm{K}^{+}\right), \mathrm{T}_{10}=(140 \mathrm{mM} \mathrm{NaCl}+5 \mathrm{mM}$ $\mathrm{B}+6 \mathrm{mM} \mathrm{K}^{+}$) were added to soil at the time of sowing for both cotton varieties in three replications. For this study, the complete randomized design (CRD) under factorial arrangement was used.

The plants were harvested at maturity, and data relating to yield and growth of cotton varieties were recorded at different $B$ and salinity levels, including (no. of branches plant ${ }^{-1}$, lint yield plant ${ }^{-1}(\mathrm{~g})$, boll radius, internodal distance, no. of bolls plant ${ }^{-1}$ and height of plant) (Figure 1B). For the determination of chlorophyll contents of second top leaf before harvesting of crop hand held Minolta-502 chlorophyll meter was used.

\section{Statistical analysis}

The calculated data of parameters were taken. All parameters were subjected to analysis of variance (ANOVA) through a software (Statistix v. 8.1), given by (Analytical Software, USA). The significance of means of treatment was showed by lettering (alphabetically) and standard error (S.E). The means of treatment were compared through LSD test (least significant difference) at (5\%) probability, and means that carrying same letters were considered non-significant statistically $(p \leq 0.05)$ (Steel et al., 1997).

\section{Results and Discussion}

Due toincrease in B and salinity levels, the agronomic attributes of cotton crop were rigorously affected on the other hand, in saline soil, improvement was observed by the $\mathrm{K}$ applications. All physical parameters such as no. of branches plant ${ }^{-1}$, intermodal distance (Table 1), boll radius (Figure 1D), plant height and lint weight (Figure 1A), under boron toxicity and saline conditions. No. of flowers plant ${ }^{-1}$ (Figure $1 \mathrm{C}$ ) were less as compared to those treatments where $\mathrm{K}^{+}$was applied. The effect of $\mathrm{K}^{+}$application was most favorable in those treatments where $\mathrm{K}^{+}$was applied in both salt and B stress as compared to untreated treatments. Same trend was observed in all growth parameters in both cotton varieties.

Table 1: Agronomic characteristics of varieties of cotton at different levels of boron (B) and salinity.

$\begin{array}{lllllll}\begin{array}{l}\text { Treat- } \\ \text { ment }\end{array} & \begin{array}{l}\text { FH-114 } \\ \text { Plant } \\ \text { height } \\ \text { (cm) }\end{array} & \begin{array}{l}\text { No. of } \\ \text { branches } \\ \text { plant }^{-1}\end{array} & \begin{array}{l}\text { Inter- } \\ \text { modal } \\ \text { distance } \\ (\mathbf{c m})\end{array} & \begin{array}{l}\text { Plant } \\ \text { height } \\ (\mathbf{c m})\end{array} & \begin{array}{l}\text { No of } \\ \text { branches } \\ \text { plant }^{-1}\end{array} & \begin{array}{l}\text { Inter- } \\ \text { modal } \\ \text { distance }\end{array} \\ \mathrm{T}_{1} & 117.6^{\mathrm{cd}} & 10^{\mathrm{c}} & 4.2^{\mathrm{d}} & 113.4^{\mathrm{b}} & 09^{\mathrm{b}} & 4.1^{\mathrm{cd}} \\ \mathrm{T}_{2} & 111.3^{\mathrm{i}} & 09^{\mathrm{de}} & 3.8^{\mathrm{e}} & 100.4^{\mathrm{g}} & 09^{\mathrm{bc}} & 3.3^{\mathrm{e}} \\ \mathrm{T}_{3} & 118^{\mathrm{c}} & 11^{\mathrm{bc}} & 4.5^{\mathrm{c}} & 113.9^{\mathrm{b}} & 10^{\mathrm{b}} & 4.4^{\mathrm{bc}} \\ \mathrm{T}_{4} & 112.7^{\mathrm{h}} & 08^{\mathrm{e}} & 3.6^{\mathrm{f}} & 100.4^{\mathrm{g}} & 06^{\mathrm{e}} & 3.3^{\mathrm{e}} \\ \mathrm{T}_{5} & 115.2^{\mathrm{f}} & 09^{\mathrm{d}} & 4.0^{\mathrm{e}} & 104.7^{\mathrm{e}} & 08^{\mathrm{c}} & 3.4^{\mathrm{e}} \\ \mathrm{T}_{6} & 116.6^{\mathrm{de}} & 10^{\mathrm{c}} & 4.3^{\mathrm{d}} & 111.2^{\mathrm{c}} & 09^{\mathrm{bc}} & 4.0^{\mathrm{d}} \\ \mathrm{T}_{7} & 119^{\mathrm{b}} & 12^{\mathrm{ab}} & 4.7^{\mathrm{b}} & 115.1^{\mathrm{b}} & 11^{\mathrm{a}} & 4.6^{\mathrm{b}} \\ \mathrm{T}_{8} & 120.6^{\mathrm{a}} & 12^{\mathrm{a}} & 5.2^{\mathrm{a}} & 117.1^{\mathrm{a}} & 11^{\mathrm{a}} & 5.0^{\mathrm{a}} \\ \mathrm{T}_{9} & 114.1^{\mathrm{g}} & 09^{\mathrm{de}} & 3.9^{\mathrm{e}} & 102.3^{\mathrm{f}} & 07^{\mathrm{d}} & 3.4^{\mathrm{e}} \\ \mathrm{T}_{10} & 116^{\mathrm{ef}} & 10^{\mathrm{c}} & 3.9^{\mathrm{e}} & 109^{\mathrm{d}} & 08^{\mathrm{c}} & 3.8^{\mathrm{d}} \\ \mathrm{LSD}_{5} & 0.9804 & 0.7455 & 0.1844 & 1.702^{2} & 0.9396 & 0.3514\end{array}$

Values with the same letter are not statistically significant $(p<0.05)$

Under toxicity of $\mathrm{B}$ and saline stress, reduction was observed in chlorophyll contents. The chlorophyll contents showed increase by $\mathrm{K}$ applications illustrated in (Figure 2). NIAB-846 showed comparatively low response, while $\mathrm{FH}-114$ showed maximum response to applied potassium. In FH-114 and NIAB-846, there was 45.8 and $40 \%$ decrease, respectively, in $\mathrm{T}_{4}$ (140 mM NaCl $+5 \mathrm{mM} \mathrm{B})$ was observed as compared to $\mathrm{T}_{1}$ where (original level of $\mathrm{k}^{+}+$recommended dose of $\mathrm{N}$ and $\mathrm{P}$ ). Potassium application was more effective to combat salinity and boron toxicity. The higher level of potassium application increases lint weight, no. of bolls and chlorophyll contents. Combined salt and B stress reduces significantly the chlorophyll contents (Figure 2). So, results proved that the combined effect of treatment B and salinity interaction/toxicity (in combination) was harmful to plants as compared 


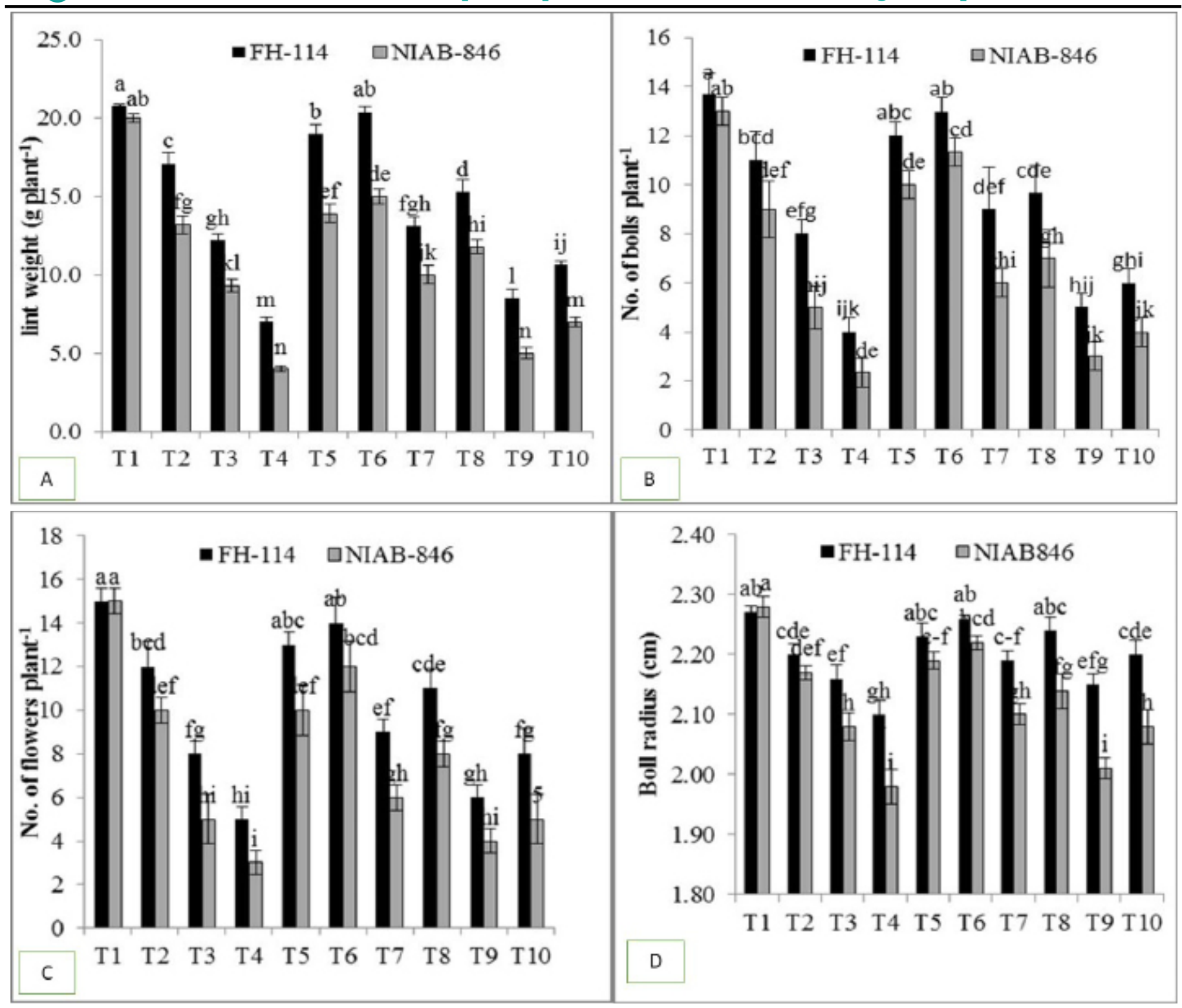

Figure 1: A) Lint weight plant $\left.{ }^{-1}, B\right)$ No. of bolls plant $\left.{ }^{-1}, C\right)$ No. of flowers plant ${ }^{-1}$ and D) Boll radius, of different cotton varieties at various $B$ and/ or salinity levels at significance level ( $p<0.05)$.

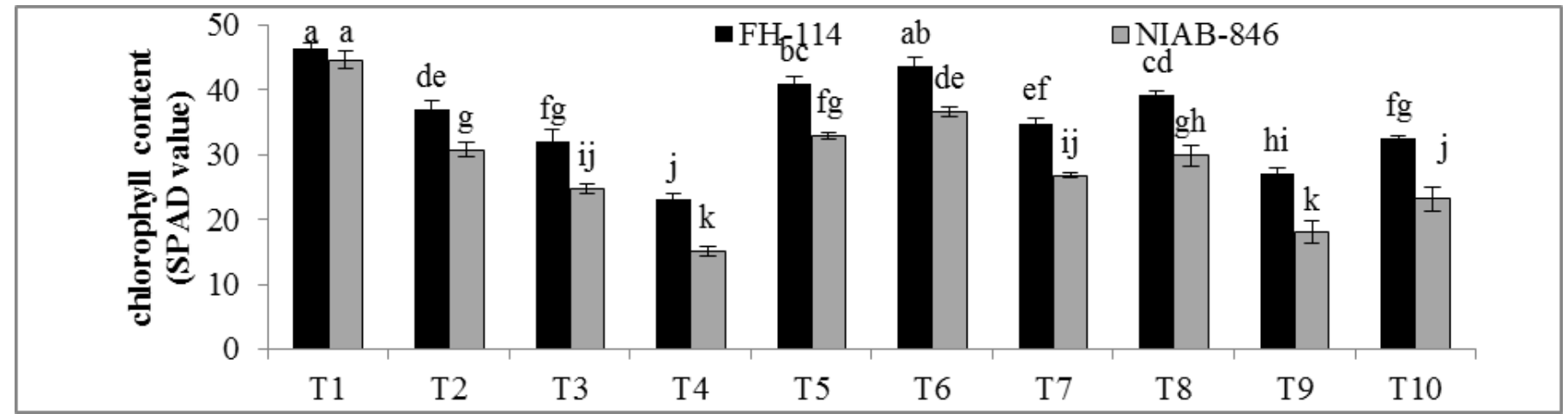

Figure 2: Chlorophyll contents of different cotton varieties at various $B$ and/ or salinity levels at significance level ( $p<0.05)$.

to other treatments. NIAB-846 showed reduces results in all parameters as compared to than $\mathrm{FH}-114$.

In salinity, decrease in yield and growth of plant are due to salinity stress. This reason of salinity changes all the characteristics of crops involving (biochemical, physiological, morphological and agronomic attributes). In all growth parameters reducing trend was observed under saline and boron stress. Adcock et al. (2007) confirmed that frequently B is present in higher concentration, and it shows a relationship with salinity (in combination). (Aftab et al., 2015) showed, 
several different results have been present on the effect of B-salinity interaction (Ashraf, 2009) declared that, cotton plant response is variable at different growth stages. Some cultivars were proved tolerant to saline conditions at seedling stage, but during later stages, it was not tolerant to salinity. (Hu et al., 2008) declared that,decreased no. of branches plant ${ }^{-1}$ and height of plantfor fertilizer application might be because of time being fertilizer stress. Under medium saline conditions osmotic adjustment of plant might be easy as compare to high saline conditions (Qados, 2011). Early growth stages of plants are salt senstive that is the main reason of decreased agronomic, biochemical and quality parameters of crops (Acosta-Motos et al., 2017). In salinty conditions, raised internodal distance and decrease in no. of branches per plantare observed and associated to peroxidation of lipid along with the reactive oxygen species (ROS) addition (Klein, 2012). Potassium $\left(\mathrm{K}^{+}\right)$has a main function in salt tolerance plant which is potassium $\left(\mathrm{K}^{+}\right)$uptake is decreased by $\mathrm{Na}^{+}$(Fox and Guerinot, 1998; Aftab et al., 2016). Moreover, Rahnama and Ebrahimzadeh (2004) has also declared, K performs an essential role in most of the physiological characteristics of plant such as, transport of sugar, enzymes activation, osmotic adjustment, starch synthesis, synthesis of ATP and protein synthesis etc.

Higher the salinity stress, markedly reduction was noted, (Akcin and Yalcin, 2016; Nawaz et al., 2010), in leaves chlorophyll contents. It is documented in literature by (Ali et al., 2004) that decline in leaves chlorophyll contents was the reason of b-carotene degradation and, (Gomes et al., 2011), the adverse effects of accumulation of salts in ions. By the application of potassium sulfate chlorophyll contents improved. Hussein et al. (2014) stated, similar results obtained in Jojoba plants. Potassium fertilizers under saline conditions enhanced photosynthetic pigments by increasing the potassium ion and reducing the sodium ions (Fayez and Bazaid, 2014; Hu et al., 2008). In the previous studies similar results were found by some other scientists (Arshadullah et al., 2014; Sharma and Minhas, 2005).

\section{Conclusion and Recommendations}

The B and salinity interaction has harmful effects on the yield and growth of two cotton varieties like NIAB-846 and FH-114. The cotton variety (FH114) towards $\mathrm{K}$ applications responds positively as compared to (NIAB-846) variety, as (FH-114) variety obtained more potassium $(\mathrm{K})$. In combined stress of boric acid $\left(\mathrm{H}_{3} \mathrm{BO}_{3}\right)$ and sodium chloride $(\mathrm{NaCl})$, $\mathrm{K}$ application was added into soil in the form of $\left(\mathrm{K}_{2} \mathrm{SO}_{4}\right), \mathrm{FH}-114$ has more potential to enhance the yield and growth as compared to the variety (NIAB846). It has been concluded that the $\mathrm{K}$ application under combined stress of salts and boron showed positive results in growth, biochemical and yield parameters of both varieties of cotton.

\section{Acknowledgment}

This article and study trial makes possible by Ayub Agriculture research Institute (AARI), Faisalabad and University of Agriculture (UAF), Faisalabad.

\section{Novelty Statement}

Toxicity of salinity-boron badly affects yield and growth parameters of cotton in stress conditions.

\section{Author's Contribution}

Muhammad Aftab: Conception and design of the work and conduction of experiment.

Aneela Riaz: Drafting and technical assistance.

Ghulam Sarwar: Supervision and technical assistance at every step.

Muhammad Arif and Qudsia Nazir: Final editing and proof-reading Interpretation of data and excel work for graphs making.

Ifra Saleem: Helped in lab. Work.

Sarfraz Hussain and Abid Ali: Interpretation of data and excel work for graphs making.

Abid Niaz and Fakhar Mujeeb: Assisted in write up and final editing of manuscript.

Khalid Mahmood: Elaborated results and discussion. Sarfraz Nawaz: Statistical analysis of data.

Conflict of interests

Authors announce no conflict of interest.

\section{References}

Abbasi, G.H., J. Akhtar, M.A. Haq, S. Ali, Z. H. Chen and W. Malik. 2014. Exogenous Potassium Differentially Mitigates Salt Stress in Tolerant and Sensitive Maize Hybrids. Pak. J. Bot., 46 (1):135-146.

Acosta-Motos, J.R., M.F. Ortuño, A. Bernal- 
Vicente, P. Diaz-Vivancos, M.J. SanchezBlanco and J.A. Hernandez. 2017. Plant responses to salt stress: adaptive mechanisms. Agronomy, 7 (1): 18. https://doi.org/10.3390/ agronomy7010018

Adcock, D., A.M. McNeill, G.K. McDonald and R.D. Arm-strong. 2007. Subsoil constraints to crop production on neutral and alkaline soils in south-eastern Australia: A review of current knowledge and management strategies. Aust. J. Expt. Agric., 47:1245-1261. https://doi. org/10.1071/EA06250

Aftab, M., G. Sarwar, M.A. Haq and A. Riaz. 2016. Role of potassium in the alleviation of combined stress of salinity and boron in cotton (Gossypium Hirsutum L.). Int. J. Agric. Appl. Sci., (IJAAS). 8(2): 218-221.

Aftab, M., M.A. Tahir, M.A. Haq and A. Riaz. 2015.Exogenous application of Potassium to combat the adverse impact of salinity and boron stress in cotton (Gossypium hirsutum L.) Int. J. Appl. Sci., 7(2): 209-211.

Akcin,A. and E. Yalcin.2016. Effect of salinity stress on chlorophyll, carotenoid content, and proline in Salicorniaprostrata Pall. and Suaedaprostrata Pall. subsp. prostrata (Amaranthaceae). Brazilian J. Bot., 39 (1):101-106. https://doi. org/10.1007/s40415-015-0218-y

Ali,M.A.,J.Farooq,A.Batool,A.Zahoor, F.Azeem, A. Mahmood and K. Jabran. 2019. Cotton productionin Pakistan. CottonProd.,249(2019). https://doi.org/10.1002/9781119385523.ch12

Ali, Y., Z. Aslam, M. Ashraf and G. Tahir. 2004. Effect of salinity on chlorophyll concentration, leaf area, yield and yield components of rice genotypes grown under saline environment. Int. J. Environ. Sci. Technol., 1 (3):221-225. https://doi.org/10.1007/BF03325836

Arshadullah, M., A. Ali, S.I. Hyder, I.A. Mahmood and B.U. Zaman. 2014. Effect of different levels of foliar application of potassium on Hysun-33 and Ausigold-4 sunflower (Helianthus annuus L.) cultivars under salt stress. Biol. Sci. PJSIR, 57(1): 1-4. https://doi.org/10.52763/PJSIR. BIOL.SCI.57.1.2014.1.4

Ashraf, M. 2009. Biotechnological approach of improving plant salt tolerance using antioxidants as markers. Biotechnol. Advan., 27:84-93. biotechadv.2008.09.003

Ashraf, M. 2002. Salt tolerance of cotton: some new advances. Crit. Rev. Plant Sci., 21:1-30. https://doi.org/10.1080/0735-260291044160

Booth, W.A. and J. Beardall.1991. Effect of salinity on inorganic carbon utilization and carbonic anhydrase activity in the halotolerantalgae Dunaliellasalina (Chlorophyta). Phycologia, 30: 220-225. https://doi.org/10.2216/i0031-8884$30-2-220.1$

Camacho, C., J. Juan, J. Rexach and A.G. Fontes. 2008. Boron in plants: deficiency and toxicity. J. Integr. Plant Biol., 50(10): 1247-1255. https:// doi.org/10.1111/j.1744-7909.2008.00742.x

Fayez, K.A. and S.A. Bazaid. 2014. Improving drought and salinity tolerance in barley by application of salicylic acid and potassium nitrate. J. Saudi Soc. Agric. Sci., 13 (1):45-55. https://doi.org/10.1016/j.jssas.2013.01.001

Flowers, T.J. and A.R. Yeo. 1995. Breeding for salinity resistance in crop plants: where next? Aust. J. Plant Physiol., 22:875-884. https://doi. org/10.1071/PP9950875

Fox, T.C. and M.L. Guerinot. 1998. Molecular biology of cation transport in plants. Ann. Rev. Plant Physiol. Plant Mol. Biol., 49: 669-696. https://doi.org/10.1146/annurev. arplant.49.1.669

Gomes, M.A.D.C., M.S. Suzuki, M.D. Cunha and C.F. Tullii. 2011. Effect of salt stress on nutrient concentration, photosynthetic pigments, proline and foliar morphology of Salviniaauriculata Aubl. Acta Limnol. Brasil., 23:164-176. https:// doi.org/10.1590/S2179-975X2011000200007

Grieve, C.M. and J.A. Poss. 2000.Wheat response to interactive effects of boron and salinity. J. Plant Nutr., 23: 1217-1226. https://doi. org/10.1080/01904160009382095

Hasegawa, P.M., R.A. Bressan, J.K. Zhu and H.J. Bohnert. 2000. Plant cellular and molecular responses to high salinity. Annu. Rev. Plant Physiol. Plant Mol. Biol., 51:463-499. https:// doi.org/10.1146/annurev.arplant.51.1.463

Hu, Y., Z. Burucs and U. Schmidhalter. 2008. Effect of foliar fertilization application on the growth and mineral nutrient content of maize seedlings under drought and salinity. Soil Sci. Plant Nutr., 54 (1):133-141. https://doi. org/10.1111/j.1747-0765.2007.00224.x

Hussein, M., H. Mehanna, S. Zaki and N.F.A. Hay. 2014. Influences of salt stress and foliar fertilizers on growth, chlorophyll and carotenoids of jojoba plants. Middle East J. 
Agric. Res., 3 (2):221-226.

Klein, A.J. 2012. Modulation of Soybean and Maize Antioxidant Activities by Caffeic Acid and Nitric Oxide Under Salt Stress Doctoral dissertation. University of the Western Cape.

Kronzucker,H.J.,M.W.Szczerba,L.M.Schulze and

D.T. Britto. 2008. Non-reciprocal interactions between $\mathrm{K}+$ and $\mathrm{Na}+$ ions in barley (Hordeum vulgare L.). J. Exp. Bot., 59(10): 2793-2801. https://doi.org/10.1093/jxb/ern139

Liebersbach, H., B. Steingrobe and N. Claassen. 2004. Roots regulate ion transport in the rhizosphere to counteract reduced mobility in dry soil. Plant Soil, 260 (1-2): 79-88. https://doi. org/10.1023/B:PLSO.0000030191.92338.6a

Majeed, A., M.F. Nisar and K. Hussain. 2010. Effect of saline culture on the concentration of $\mathrm{Na}^{+}, \mathrm{k}^{+}$and $\mathrm{Cl}^{-}$in Agro stistolonifera. Curr. Res. J. Biol. Sci. 2(1):76-82.

Marschner, H. 1995. Mineral nutrition of higher plants, 2nd Ed. Academic Press, London. pp. 889.

Moodie C., H. Smith and R. McCrery. 1959. Laboratory manual for soil fertility. Washington USA: Department of Agronomy, State College of Washington Pullman.

Munns, R. and M. Tester. 2008. Mechanisms of salinity tolerance. Ann. Rev. Plant Biol., 59:651-681. https://doi.org/10.1146/annurev. arplant.59.032607.092911

Nable, R.O., G.S. Banuelos and J.G. Paull. 1997. Boron toxicity. Plant Soil., 193:181-198. https://doi.org/10.1023/A:1004272227886

Nawaz, K., K. Hussain, A. Majeed, F. Khan, S. Afghan and K. Ali. 2010. Fatality of salt stress to plants: Morphological, Physiological and biochemical aspects. Afr. J. Biotechnol., 9(34): 5475-5480.

Pandey, A., M.K. Khan, E.E. Hakki, S. Gezgin and M. Hamurcu. 2019. Combined boron toxicity and salinity stress-An insight into its interaction in plants. Plants, 8(10): 364. https:// doi.org/10.3390/plants8100364

Qados, A.M.A. 2011. Effect of salt stress on plant growth and metabolism of bean plant (Vicia faba L.). J. Saudi Soc. Agric. Sci., 10 (1):7-15. https://doi.org/10.1016/j.jssas.2010.06.002

Qi, Z. and E.P. Spalding. 2004. Protection of plasma membrane $\mathrm{k}+$ transport by the salt overly sensitive $1 \mathrm{Na}^{+}-\mathrm{H}^{+}$antiporter during salinity stress. Plant Physiol., 136(1):25472555. https://doi.org/10.1104/pp.104.049213

Rahnama, H. and H. Ebrahimzadeh. 2004. The effect of $\mathrm{NaCl}$ on proline accumulation in potato seedlings and calli. Acta Physiol. Plant, 26:263-270. https://doi.org/10.1007/s11738004-0016-9

Rana, A.W., A. Ejaz and S. H. Shikoh. 2020. Cotton crop: A situational analysis of Pakistan. Int. Food Policy Res. Inst., 2020. https://doi. org/10.2499/p15738coll2.133702

Rengel, Z. and P.M. Damon. 2008. Crops and genotypes differ in efficiency of potassium uptake and use. Physiologia Plantarum, 24(2):105-110. https://doi.org/10.1111/ j.1399-3054.2008.01079.x

Richards, L.A. 1954. Diagnosis and Improvement of Saline and Alkali Soils. Handbook No. 60, United States Salinity Laboratory Staff. California, USA.

Sharma, B.R. and P.S. Minhas. 2005. Strategies for managing saline/alkali waters for sustainable agricultural production in South Asia. Agric. Water Manag., 78:136-151. https://doi. org/10.1016/j.agwat.2005.04.019

Steel, R.G.D., J.H. Torrie and D.A. Dickey.1997. Principles and Procedures of Statistics: A Biometrical Approach, 3rd edition McGraw Hill Co., New York, USA.

Syed, A., G. Sarwar, S.H. Shah and S. Muhammad. 2021. Soil Salinity Research in $21^{\text {st }}$ Century in Pakistan: Its Impact on Availability of Plant Nutrients, Growth and Yield of Crops. Commun. Soil Sci. Plant Anal., 52(3): 183-200. https://doi.org/10.1080/00103624.2020.1854 294

Watanabe, F. and S. Olsen. 1965. Test of an ascorbic acid method for determining phosphorus in water and $\mathrm{NaHCO}_{3}$ extracts from soil 1. Soil Sci. Soc. Am., 29(6):677. https://doi.org/10.2136/ sssaj1965.03615995002900060025x 